\title{
Assessment of the Contribution of Road Traffic to Greenhouse Emissions: A Case of an Algerian City
}

\author{
Aouragh Leila1, Bourmada Noureddine ${ }^{2}$ \\ ${ }^{1}$ LRNAT Laboratory, Institute of Hygiene and Industrial Security, University of Batna, Batna, Algeria \\ ${ }^{2}$ LARPI Laboratory, Institute of Hygiene and Industrial Security, University of Batna, Batna, Algeria \\ Email: laouragh@yahoo.fr
}

Received 23 August 2014; revised 15 September 2014; accepted 12 October 2014

Copyright (C) 2014 by authors and Scientific Research Publishing Inc.

This work is licensed under the Creative Commons Attribution International License (CC BY).

http://creativecommons.org/licenses/by/4.0/

(c) (i) Open Access

\begin{abstract}
Rapid urbanisation brings about increase in air pollution. These emissions are generally linked to the production of energy, to industrial activities and to transport in the densely inhabited areas. Estimating the pollutants quantities released in the air is an important stage in the evaluation of air quality. However, the problem of air pollution in urban areas is a problem in all Algerian cities. Similar to all Algerian big cities, the city of Batna has become a major urban area with an ever increasing fleet of motor vehicles most of which are practically old ones. This state of affairs increases the demand in fuel consumption and undeniably intensifies polluting emissions. As the situation goes, it has become the utmost urgency to wonder about a possible support that may be given to this sector in order to evaluate how air quality is managed in a durable way. The main objective of this study is to assess the quantity of $\mathrm{CO}_{2}$ pollutant known as the most significant greenhouse gas emission from traffic. The approach used is mainly based on a number of assumptions, which allows us to find the amount of $192 \mathrm{~g} / \mathrm{km} / \mathrm{day} \mathrm{CO}_{2}$ released into the urban atmosphere of the city of Batna.
\end{abstract}

Keywords

Air Pollution, Road Transport, Greenhouse Gas, Emission Factors, Impact

\section{Introduction}

During the last decade, societies have witnessed greater industrial growth and disproportionate energy consumption which have brought about emission of greenhouse effect gas (GEG). Therefore, these societies face serious 
problems due to air pollution such as greenhouse effect or human health problems [1]. At the present time, the major cause of the bad quality of air in the European cities has proved to be road transport [2]. Moreover, the multiple local plans in favour of a better air quality show that air in cities and rural areas has become one of the priorities within the local and national policies [3]. This is because it is always in cities that a great pressure is exerted on the environment due to the very high consumption levels of resources which are essentially linked to car traffic and house heating [4] [5] and which, hence, generate more important and very diversified air pollution. We should note that in urban environment, road transport activities are the first causes of air quality degradation [6].

Atmospheric pollution generated by road transport constitutes a real public health issue that should be handled by the authorities both at a regional and an urban level [7] [8]. Furthermore, sound and atmospheric pollutions seem to be nowadays the first environmental nuisance which is directly felt by the population on a local scale and threatens human health [7] [9]. The World Health Organisation, with reference to the recent evaluations [10] [11] has suggested that certain effects on health show closer links with the particles fine fraction and recommended regulating $\mathrm{M}_{2.5}$ instead of $\mathrm{PM}_{10}$. This is while considering that the very high levels of these emissions cause many respiratory and cardiovascular diseases [12]. Many epidemiological studies have established a clear link between transport and diseases such as asthma, bronchitis, heart attacks and cerebrovascular accidents (CVA) [13] [14].

Moreover, the interest in the nuisances of car traffic has gradually changed into a real concern in societies [15], which incited the public authorities to maintain a healthier air close to areas with denser traffic [3] [16] [17].

Motor vehicles are indeed the cause of many externalities such as air pollution, traffic jam, noise and lack of road safety. The latter is a universal problem that causes a lot of human casualties and material damage. This has pushed the WHO to stress the importance of such an impact and to declare the period 2011-2020 as "the decade of action for road safety" [18].

However, emissions caused by traffic or indirectly generated by photochemical reactions will remain one of the main sources of pollution in urban areas and constitute a serious danger for human health [19]-[21], despite important technical breakthroughs in engine technology and in fuel composition [22]. Hence, some researchers estimate that around $70 \%$ of the $\mathrm{NO}_{\mathrm{x}}$ released in the atmosphere of the big cities are due to road traffic [23].

In Algeria, as in most countries, there is more and more consideration of the degradation of air quality in urban environment and its impact on public health because of road traffic [24]-[27]. Moreover, many studies undertaken recently in Algeria show that road traffic is undoubtedly the major source of pollution in urban areas [28] [29].

Polluting emissions of motor vehicles constitute not only a problem for the quality of air in cities like Algiers [28] [30]-[32] but also an ever growing source of greenhouse effect gas.

The city of Batna, as one of the big Algerian cities, is not an exception. Knowing that this city has become a metropolis and glancing at the fleet of motor vehicles it contains, one cannot help noticing anomalies that raise highly important questions concerning public health and the preservation of the environment. In the absence of any previous study that deals with this type of pollution in the city of Batna, this work aims at investigating the polluting emissions that are caused by road traffic and their impact on air quality in the city of Batna.

\section{State of Transports and the Resulting Nuisances}

Batna, as an urban area, has presently become a big centre with people moving in and out causing weak mobility and sometimes traffic jams especially at the rush hours. Transport changes occur mostly at the city centre where there is the greatest rate of urbanization (89.4\%) [33]. The number of inhabitants increased from 236,669 in 1995 to 302,585 in 2008, which increased demand on transport [34]. This implies no doubt over consumption of fuels which causes increase in atmospheric pollution. The motor vehicules fleet consisted of 31,279 motor vehicles on 31 December 2005 and increased to 95,239 motor vehicles on 31 December 2013. This number consists of many categories as shown in Figure 1. We notice a big proportion of light vehicles (65.52\%) [35]. Distribution according to age is illustrated in Figure 2, where we notice that the fleet is dilapidated since about $60 \%$ are over 20 years of age and release more pollutants.

A further problem is that the mobility rate of property and people may lead to development and progress and 


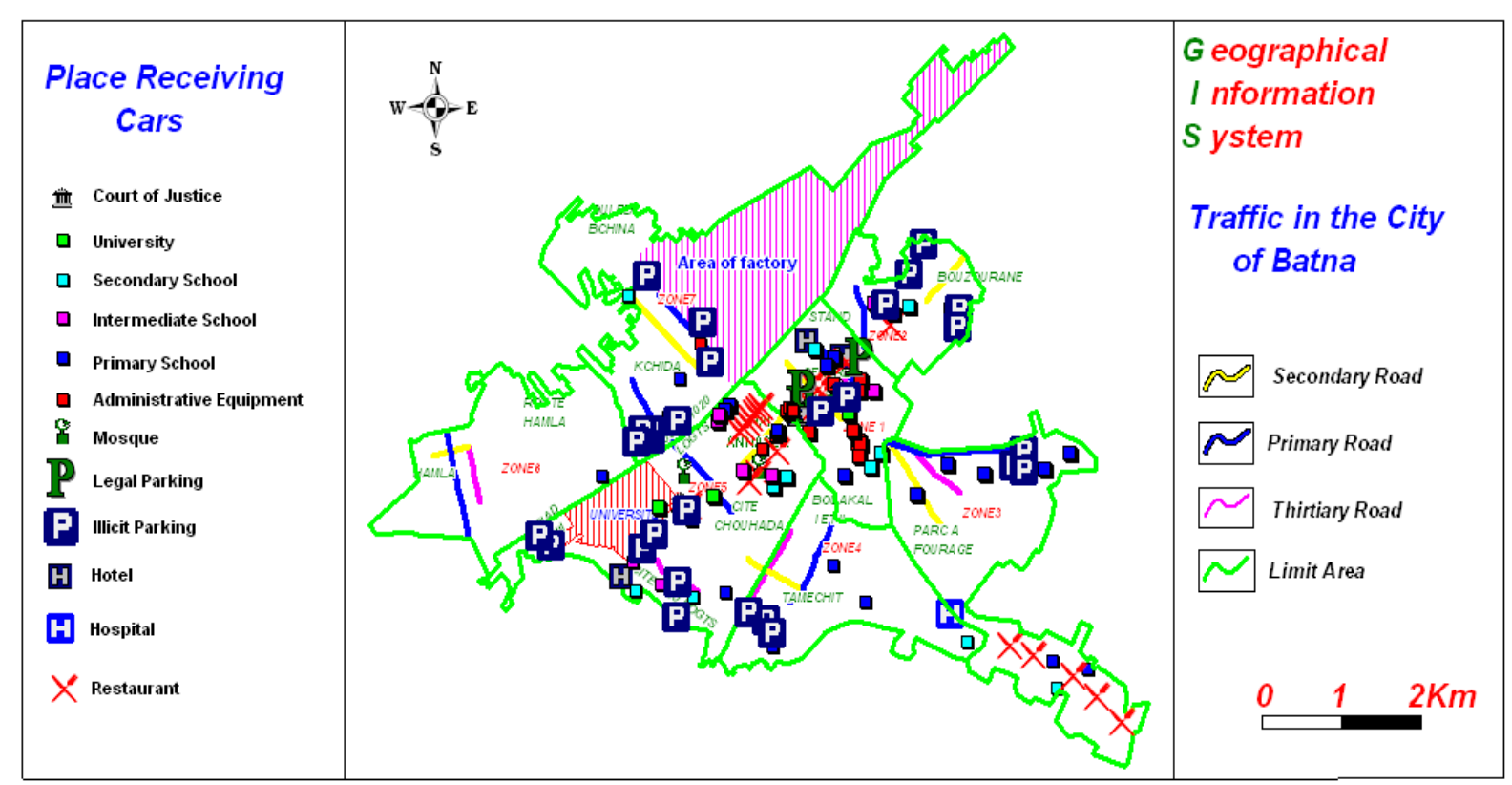

Figure 1. Mapping of the city of Batna.

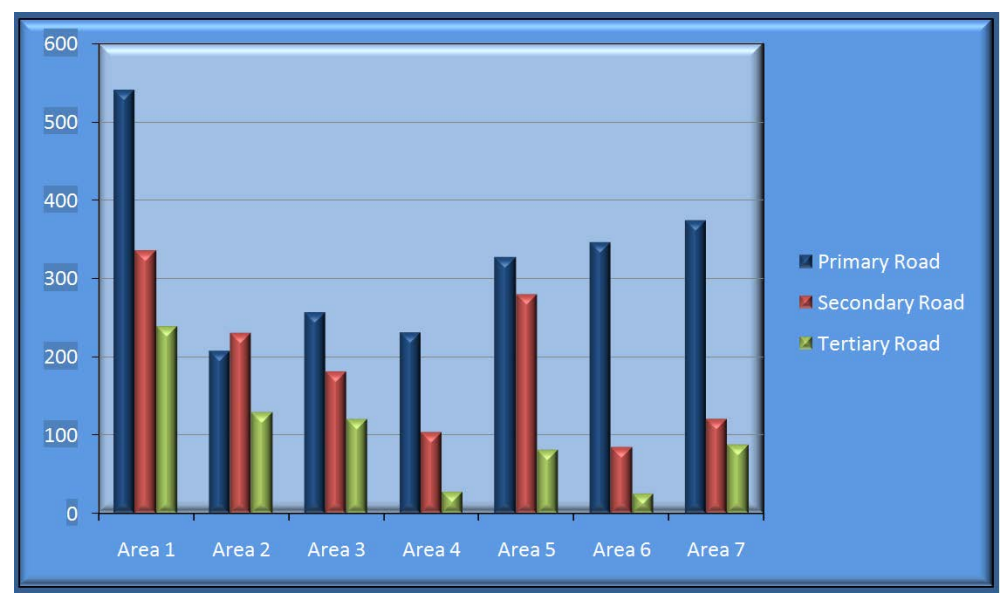

Figure 2. Illustration of the average rush hour flow for each area and each road category.

may cumulate in delays that cause partial or global congestions. The places of such congestions differ in their evolution and have complex causes. As it is the case of all cities, the city centre has many streets with extremely dense traffic in comparison with their width and the state of their roads. We must also note that there is growing congestion in ring roads as well.

In this respect, we carried out an investigation (during two years 2012-2013) in order to estimate the number of motor vehicles which access the city through its main entrances and which constitute an agravating factor of road congestion. The results reinforce this hypothesis [5].

The investigation consisted of selecting the roads that are representative in terms of the flow and density of traffic as well as the type of road (main, secondary and tertiary) taking into account that the city of Batna has been divided into 7 areas, in accordance with the municipal code (Figure 1).

We had to spend two years of field investigation and assessment in order to select the area to study and determine the daily average rush hour (Figure 2). This allowed us to decide on an average that is reproducible, significant and representative of what remains of our work.

The obtained results are illustrated in Table 1. 
Table 1. Distribution of the average rush hour flow for each area.

\begin{tabular}{|c|c|c|c|c|c|c|c|}
\hline Areas $\quad$ Roads & Area 1 & Area 2 & Area 3 & Area 4 & Area 5 & Area 6 & Area 7 \\
\hline Main Road (Vehicle) & 539.33 & 208 & 257 & 231.66 & 327 & 345.66 & 374.33 \\
\hline Secondary Road (Vehicle.) & 334.33 & 230 & 181.33 & 103.66 & 278.66 & 85 & 120.66 \\
\hline Thirtiary Road (Vehicle.) & 239.33 & 129.33 & 121 & 28.66 & 81.33 & 26 & 88.33 \\
\hline Average Vehicle & 1112.99 & 567.33 & 559.33 & 363.98 & 286.99 & 456.99 & 583.32 \\
\hline Average Rush Hour (mn) & $\begin{array}{c}10 \\
10.66 \\
5.16\end{array}$ & $\begin{array}{c}4.83 \\
7 \\
34.33 \mathrm{~s}\end{array}$ & $\begin{array}{c}8.16 \\
11 \\
7.66\end{array}$ & $\begin{array}{c}11 \\
8.33 \\
6.33\end{array}$ & $\begin{array}{c}13.66 \\
8.33 \\
6\end{array}$ & $\begin{array}{l}5 \\
3 \\
4\end{array}$ & $\begin{array}{c}8 \\
9.66 \\
6.66\end{array}$ \\
\hline
\end{tabular}

\section{Evaluation of Pollutants Quantity}

Our approach consists of acquiring data which have a link with spatio-temporal dimensions.

The processing of these data is summarized in Figures 2-6.

Figure 3 and Figure 4 illustrate the distribution of motor vehicles by age and category. This distribution shows clearly fluctuations between the years 2010 and 2013 which reflect the policies of the departments in charge of purchasing various types of vehicles. This also shows that the fleet is on the increase in category, age and fuel type. This will allow us to highlight the influence of the old age of the fleet as well as the fuel that is used on the urban air quality through the following pollutants: $\mathrm{CO}_{2}, \mathrm{CO}, \mathrm{NO}_{\mathrm{x}}$, and the total airborne particles (TAP), which are pollutants with greenhouse effect.

Figure 5 and Figure 6 show the remarkable change in the way fuel has been used since 2011. This can be explained by the low price of diesel as well as the lifespan of the diesel engine compared to the petrol one.

In order to quantify the impact of these pollutants, we have recourse to the emission factors which allow us to estimate their concentrations. This approach will allow us to estimate the $\mathrm{CO}_{2}$ concentration in proportion to a limited space.

To estimate the quantity of the released $\mathrm{CO}_{2}$, we determine the temporal space, in accordance with the obtained results of our investigation i.e. the number of vehicles, the trail distance and time as well as the number of vehicles running during the rush hour (Table 2).

If we suppose, according to the OEE (Office of Efficiency Energetics, Ecoflootte Program), that a vehicle consumes 4 litres of fuel per hour, the overall number of vehicles will consume 1915, 844 litres of fuel. According to the Direction of the Reglementation and General Administration (DRAG), 49.38\% of all vehicles consume petrol and the rest consume diesel. Considering the density of diesel and petrol, which are 0.845 and 0.755 respectively, and in order to determine the quantity of the consumed carbon by both fuels, we use the two emission factors namely 20.20 tons per terra joule for diesel and 18.90 tons per terra-joule for petrol. By resorting to the Terra-joule unit and considering that $99 \%$ of carbon is oxidized, the emission contents of carbon in diesel and petrol are 0.733 and 0.592 tons respectively.

Furthermore, the overall quantity of $\mathrm{CO}_{2}$ released in the city, during the year 2013, where there is an average number of vehicles of 95,239 (Table 3) is 1140118.01 tons of $\mathrm{CO}_{2}$. This is considering that a vehicle runs an average of $170 \mathrm{~km} /$ day, a petrol vehicle consumes an average of 6.7 liters $/ 100 \mathrm{~km}$ and a diesel one consumes 8.46 liters $/ 100 \mathrm{~km}$.

\section{Discussion}

The work that has been undertaken, concerning the city of Batna is to verify hypotheses taking into account the number and the categories of motor vehicles as well as the distance run and the average fuel consumption. It has allowed us to estimate the role of pollutants emissions with greenhouse effect which are generated by the road transport sector.

We note a certain number of problems caused by demographic growth, the saturation of the road network, the old age of the motor vehicle fleet and traffic congestion. These lead to deterioration of air quality with an impact on human health, degradation of the ecosystem and especially reduction of life quality.

In Batna, the consequences of atmospheric pollution start to weigh on the population by an unbreathable atmosphere leading to an increase in respiratory diseases. This is caused by the release of allergens in the environment by engines, exhaust pipes, air conditioners and worn tyres, particularly in areas where traffic is very 


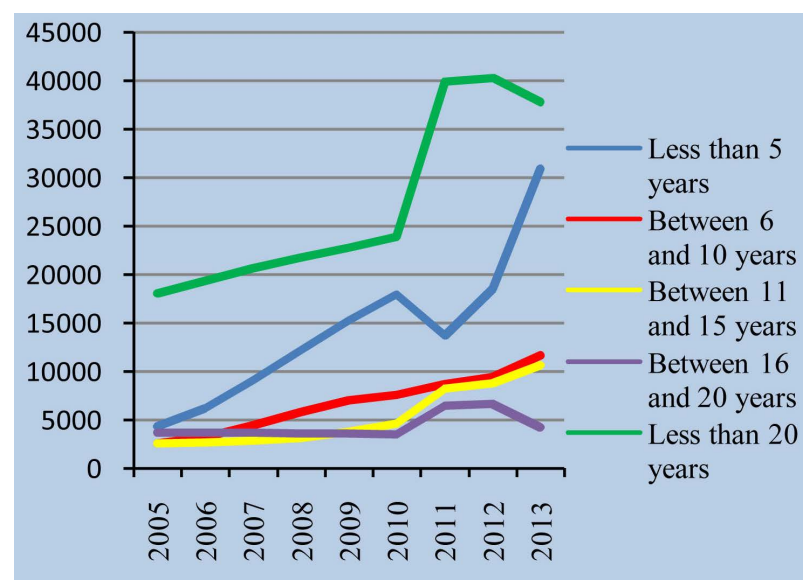

Figure 3. Evolution of the motor car fleet in age and category.

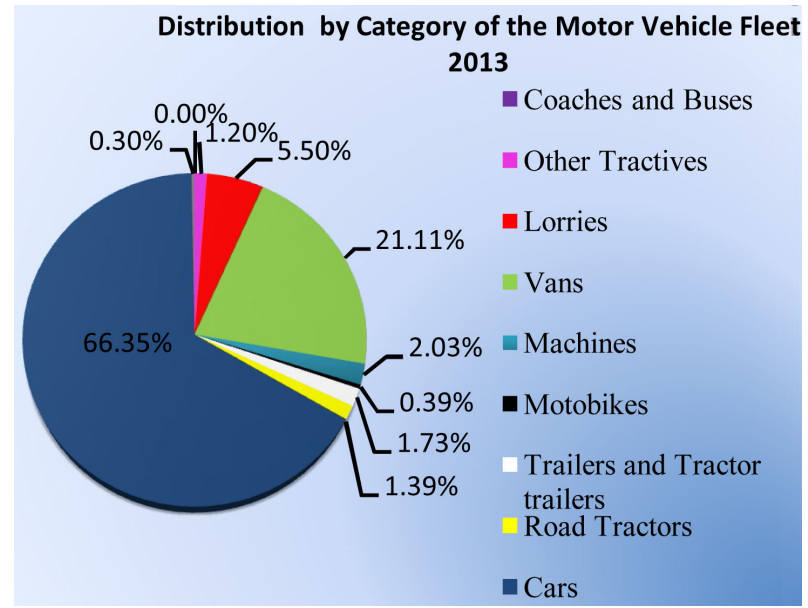

Figure 4. Distribution of the motor vehicle fleet 2013.

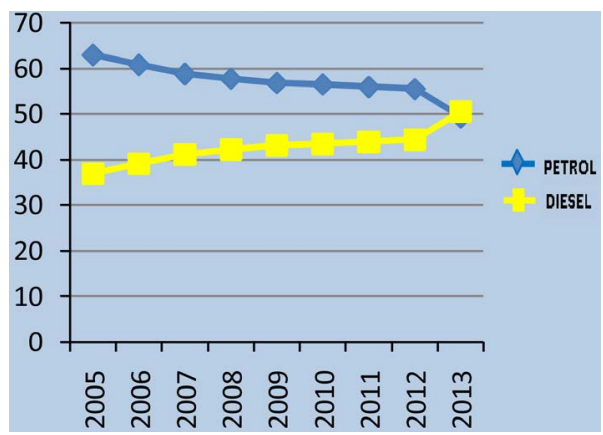

Figure 5. Evolution of motor car fleet in fuel.

dense. It is estimated that more than $50 \%$ of emissions are caused by road transport as the city is not very industrilized and there is constant increase in the sales of fuel.

The urban air quality is essentially linked to the type of motor vehicles, the quality of the engine and fuel, the presence of a catalytic converter, the transported load and the speed of the vehicle. The speed is reduced in an urban area where traffic is in constant increase, which favours the emission of $\mathrm{CO}_{2}, \mathrm{CO}, \mathrm{NO}_{\mathrm{x}}$ and $\mathrm{PM}$ due to overconsumption of fuel with reduced movement efficiency. These result in pollution peaks with the impacts that characterize each pollutant [36]. The phenomenon extends from a local pollution to a regional and a global one. 


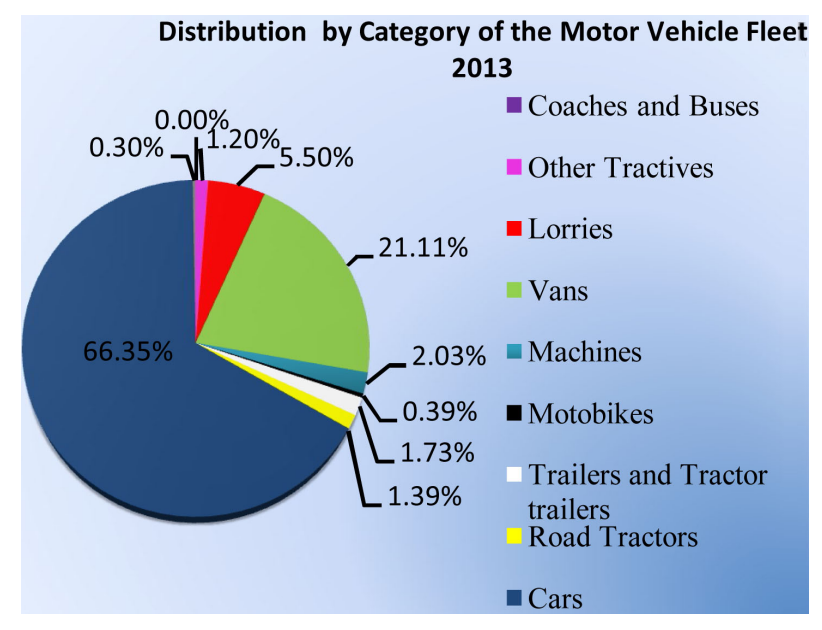

Figure 6. Evolution of fuel sales.

Table 2. Number of vehicles during the rush hour in the selected space.

\begin{tabular}{cccccc}
\hline Category & $1973-1992$ & $1993-1997$ & $1998-2002$ & $2003-2007$ & $2008-2012$ \\
\hline VP & 40 & 17 & 163 & 131 & 232 \\
VUL & 0 & 1 & 12 & 8 & 32 \\
Bus & 5 & 3 & 7 & 2 & 1 \\
\hline
\end{tabular}

Table 3. Evolution of the motor vehicle fleet in energy source.

\begin{tabular}{|c|c|c|c|c|c|c|c|c|c|}
\hline \multirow{2}{*}{ Energy Source } & \multicolumn{9}{|c|}{ Number of Vehicles/Year of Traffic } \\
\hline & 2005 & 2006 & 2007 & 2008 & 2009 & 2010 & 2011 & 2012 & 2013 \\
\hline Diesel & 11,443 & 13,764 & 16,739 & 19,722 & 22,639 & 25,024 & 32,830 & 35,728 & 58,110 \\
\hline Petrol & 19,836 & 21,362 & 23,916 & 26,979 & 29,844 & 32,549 & 44,281 & 47,816 & 37,129 \\
\hline
\end{tabular}

In order to reinforce the obtained results a second method proves useful and which starts from the following hypotheses:

- An average motor vehicle produces between 100 and $300 \mathrm{~m}^{3}$ of exhaust pipe gas per hour;

- There are 3 phases during day time which represent the rush hour periods and which equal 1 hour/day of maximum traffic;

- A light motor vehicle produces 0.02 tons of $\mathrm{CO}_{2}$ for each $100 \mathrm{~km}$ run;

- In all cases, the maximal values are kept.

In order to be able to compare the two results using the two methods, we will consider the same number of vehicles which is 95,239 in the year 2013 and we will assume that a vehicle runs as an average distance 170 $\mathrm{km} /$ day; we find a daily emission of 3238.126 tons. This corresponds to a total yearly emission of 1,181,916 tons of $\mathrm{CO}_{2}$. We notice that when using the two methods the results match perfectly with an error coefficient of $3.53 \%$.

Moreover, using the pollutants emission factors: $\mathrm{CO}, \mathrm{NO}_{\mathrm{x}}$ and $\mathrm{PM}_{2.5}$ which are: 7.5, 0.64, and $0.060 \mathrm{~g} / \mathrm{km} / \mathrm{veh}$ respectively [22] and with the same approach, the results obtained are shown in Table 4 and Figure 7.

In order to match the situation with the various norms and limiting the concentrations of the various pollutants released linked to urban transport, we had to recalculate the emissions only for private vehicles for the year 2013. They constitute 66.35\% of the overall motor vehicle fleet (Figure 4). The result is a $\mathrm{CO}_{2}$ emission of 192 $\mathrm{g} / \mathrm{km} /$ day relatively higher than the European norm, which is $130 \mathrm{~g} / \mathrm{km} / \mathrm{veh}$ CEE (the European Commission on $\mathrm{CO}_{2}$ emissions from cars).

Concerning CO, we find the $11.446 \mathrm{~g} / \mathrm{km}$.veh value which is relatively higher than the Algerian norm, somewhere between 1 and $2.3 \mathrm{~g} / \mathrm{km} / \mathrm{veh}$ [37]. This may be explained in terms of human behavior reflected in ill driving and traffic jam due to slow driving during the rush hours.

Finally, concerning the average content of particles (PM), the calculated value is $0.091 \mathrm{~g} / \mathrm{km} / \mathrm{veh}$, which ex- 
Table 4. Evolution of greenhouse effect polluants per years.

\begin{tabular}{cccccccccc}
\hline Years/Tons & 2005 & 2006 & 2007 & 2008 & 2009 & 2010 & 2011 & 2012 & 2013 \\
\hline $\mathrm{CO}_{2}$ & 377763.68 & 423628.12 & 489678.89 & 562115.69 & 631338.67 & 692424.71 & 927082.11 & 1004124.85 & 1140118.01 \\
$\mathrm{NO}_{\mathrm{x}}$ & 12.42 & 13.95 & 16.14 & 18.54 & 20.84 & 22.86 & 30.62 & 33.17 & 37.82 \\
$\mathrm{PM}$ & 1.16 & 1.31 & 1.51 & 1.74 & 1.95 & 2.14 & 2.87 & 3.11 & 3.54 \\
$\mathrm{CO}$ & 145.56 & 163.46 & 189.20 & 217.33 & 244.24 & 267.93 & 358.85 & 388.79 & 443.21 \\
\hline
\end{tabular}

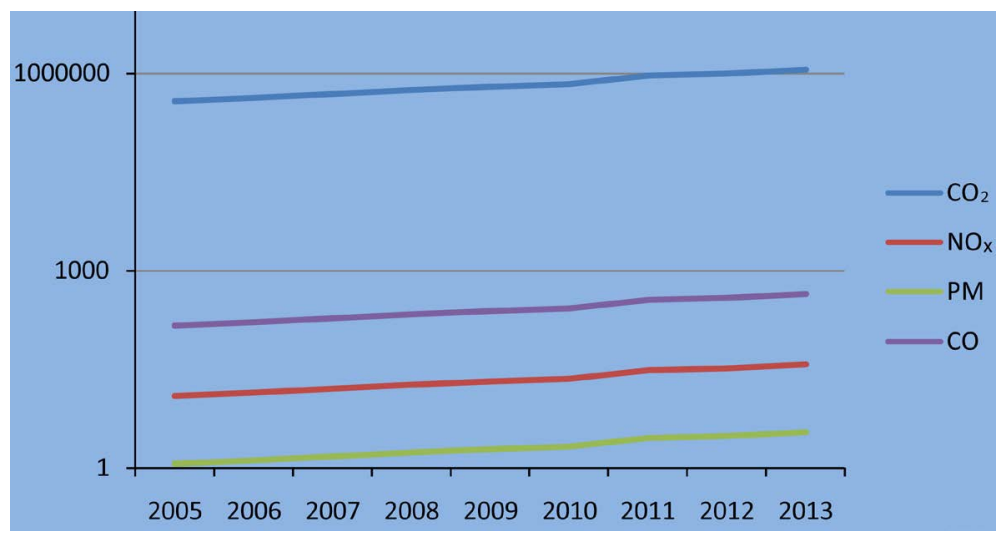

Figure 7. Evolution of polutants per years.

ceeds the de $0.05 \mathrm{~g} / \mathrm{km} / \mathrm{veh}$ norm [37].

In addition, many studies dealing with this problem have been achieved. For instance, the evaluation carried out at the loir-cher-France department [38] on a population similar to that of the city of Batna but with a motor vehicule fleet 39 times higher. The results of this study show that the same quantity of $\mathrm{CO}_{2}$ is released in both cases. Another work bears on the city of Algiers [37], with a population and a fleet ten times higher and the result is a $13,772 \mathrm{ton} / \mathrm{d} / \mathrm{veh}$ value of $\mathrm{CO}_{2}$ release, which is four times higher than that found. This shows that the value we found exceeds to a large extent the norms. It is explained by a great traffic congestion that causes overconsumption of fuel and results in great $\mathrm{CO}_{2}$ pollution. As far as the rest of the pollutants the quantity is reasonable.

The technical efforts to reduce the $\mathrm{CO}_{2}$ emissions have proved useless so far because they remain closely linked to the fuel consumption volume. That is why action should bear directly on car driving and notably on the traffic volume and requires a good understanding of the evolution of the motor vehicle fleet and the human need of movement.

\section{Conclusions}

Road transport is more and more important nowadays with the increase in the number of motor vehicles. The impact of road transport evolution on air quality is significant. Its consequences are in terms of a higher number of accidents, hazards to public health, urban saturation, overconsumption of non-renewable energy and landscape deterioration.

The rapid and disproportionate urban growth of the city of Batna has had negative impacts on its traffic projects leading to overloading some traffic axes, reducing mobility, and on the other hand, to traffic congestions particularly at the rush hours. These forcibly imply over consumption of fuel, increase in atmospheric and sound pollution, and emission of $\mathrm{CO}_{2}$ is higher than ever. Extrapolating these results for 2020, increase of $\mathrm{CO}_{2}$ by $75 \%$ is shown. The same extrapolation is carried out for the Algerian capital for 2020, which gives 2.3 million tons of $\mathrm{CO}_{2}$ [36]. This further shows that emissions in the city of Batna are very important.

In order to face up to this type of problem, there may be many solutions. At a local level, a certain number of adjustments are necessary in terms of motor vehicle traffic management especially at the most significantly hot spots. There ought to be better road signals, controlled parking areas newly thought and reflected upon transport and traffic plans and more encouraging measures by the authorities for the use of less polluting fuel such as LPG and natural gas for vehicles (GNV). 
This study has permitted assessing the impact of transport on air quality. The task then is to establish a balance between the mobility of urban transport and the caused rate of urban pollution.

A more profound study would be necessary in order to determine the distribution and the lifespan of the pollutants with regard to the global city in order to set the appropriate mapping.

Finally, the city of Batna has to take necessary measures in order to reduce greenhouse effect gas emissions (GEG) and harmful pollutants while elaborating the necessary tools for supervising and assessing air quality and its future evolutions. Such assessments will be at the disposal of the local authorities and decision makers.

\section{References}

[1] Tuiaa, D., Ossés de Eicker, M., Zah, R., Osses, M., Zarate, E. and Clappier, A. (2007) Evaluation of a Simplified Top-Down Model for the Spatial Assessment of Hot Traffic Emissions in Mid-Sized Cities. Atmospheric Environment, 41, 3658-3671. http://dx.doi.org/10.1016/j.atmosenv.2006.12.045

[2] EEA (European Environment Agency) (2011) Air Quality in Europe: Reports. EEA, Copenhagen.

[3] MEDDTL (2011) Les enjeux atmosphériques: Etat des lieux France-Région pour l'élaboration des SRCAE, juillet 2011. Ministere de l'Ecologie du Developpement Durable, du Transport et du Logement, Revue régionale Bourgogne. www.developpement-durable.gouv.fr

[4] De Ridder, K., et al. (2008) Simulating the Impact of Urban Sprawl on Air Quality and Population Exposure in the German Ruhr Area, Part I: Reproducing the Base State. Atmospheric Environment, 42, 7059-7069. http://dx.doi.org/10.1016/j.atmosenv.2008.06.045

[5] Adolehoume, A. and Zoro, B.N. (2002) A comme abidjan ou le système Gbakas in GODARDX, les transports de la ville en afrique au sud du sahara, le temps de la débrouille et du desordre inventif Paris/arceuilkarthale INRETS.

[6] Ho, B.Q., Clapier, A. and Golay, F. (2011) Air Pollution Foreacast for HO ChiMinh City, Vietnam in 2015 and 2020 , Air Quality. Atmosphere \& Health, 4, 1873-9318.

[7] Makri, A. and Stilianakis, N.I. (2008) Vulnerability to Air Pollution Health Effects. International Journal of Hygiene and Environmental Health, 211, 326-336. http://dx.doi.org/10.1016/j.ijheh.2007.06.005

[8] Roussel, I. (2010) Développement durable et Territoire Chapitre 23: Pollution atmospherique locale et développement durable. Zuindeau, B., Ed., Septentrion Villeneuve d'Ascq, 291-313.

[9] PRIMEQUAL (2009) Pollutions atmosphériques et santé environnementale. Quels enjeux? Quels acteurs? Quelles préventions? Convention PRIMEQUAL-PREDIT, Paris.

[10] WHO (2003) Health Aspects of Air Pollution with Particulate Matter, Ozone and Nitrogen Dioxyde. WHO, Geneva.

[11] Pope III, C.A., Burnett, R.T., Thurston, G.D., Thun, M.J., Calle, E.E., Krewski, D. and Godleski, J.J. (2004) Cardiovascular Mortality and Long Term Exposure to Particular Air Pollution, Epidemiological Evidence of General Pathological Pathways of Disease. Circulation, 109, 71-77.

[12] Fisher, G.W., Rolfe, K.A., et al. (2002) Health Effects Due to Motor Vehicle Air Pollution, in New Zealand. http://www.transport.govt.nz/research/Documents/health-effects-of-vehicle-emissions.pdf

[13] Zmirou, D., Gauvin, S., Pin, I., et al. (2004) Traffic Related Air Pollution and Incidence of Childhood Asthma: Results of the Vesta Case-Control Study. Journal of Epidemiology and Community Health, 58, 18-23.

[14] HEI Accountability Working Group (2003) Assessing Health Impacts of Air Quality Regulations: Concepts and Methods for Accountability Research. Health Effects Institute, Boston.

[15] Victoria Transport Policy Institute (2013) Transportation Cost and Benefit Analysis II-Air Pollution Costs. www.vtpi.org

[16] Roussel, I. (2006) Climatologie géographique et pollution atmosphérique: Quelles synergies? In: Climat et société: l'apport des géographes-climatologues, Journées de la Climatologie. http://scholar.google.fr/schocal?q=related:Piah VLt2QhsJ: scholar.google.com/\&hl=fr\&as_sdt=0.5

[17] Silva-Sánchez, S. and Sánchez, L.E. (2008) Tiering Strategic Environmental Assessment and Project Environmental Impact Assessment in Highway Planning in São Paulo, Brazil. Journal of Environmental Impact Assessment Review, 28, 515-522.

[18] World Health Organization, WHO (2008) Air Quality and Health. http://www.who.int/mediacentre/factsheets/fs313/en/index.html.

[19] Hoek, G., Brunekreef, B., Verhoeff, A., van Wijnen, J. and Fischer, P. (2000) Daily Mortality and Air Pollution in the Netherlands. Journal of the Air and Waste Management Association, 50, 1380-1389. http://dx.doi.org/10.1080/10473289.2000.10464182

[20] Nyberg, F., Gustavsson, P., Järup, L., Bellander, T., Berglind, N., Jakobsson, R., Pershagen, G., et al. (2000) Urban Air 
Pollution and Lung Cancer in Stockholm. Epidemiology, 11, 487-495. http://dx.doi.org/10.1097/00001648-200009000-00002

[21] Dab, W., Ségala, C., Dor, F., Festy, B., Lameloise, P., Le Moullec, Y., Le Tertre, A., Médina, S., Quénel, P., Wallaert, B. and Zmirou, D. (2001) Pollution atmosphérique et santé: Corrélation ou causalité? Le cas de la relation entrel'exposition aux particules et la mortalité cardio-pulmonaire. Journal of the Air and Waste Management Association, 51, 203-219. http://dx.doi.org/10.1080/10473289.2001.10464268

[22] Ghenu, A., Rosant, J.M. and Sini, J.F. (2008) Dispersion of Pollutants and Estimation of Emissions in a Street Canyon in Rouen, France. Environmental Modeling \& Software, 23, 314-321. http://dx.doi.org/10.1016/j.envsoft.2007.05.017

[23] Joumard, R. (1989) Quels polluants? Contribution des transports. Pollution atmosphérique, 121, 5-8.

[24] Azri, C., Maalej, A., Tlili, A. and Medhioub, K. (2002) Caractérisation du niveau de pollution atmosphérique dans la ville Sfax (Tunisie): Influence des sources et des facteurs météorologiques. Techniques, Sciences, Méthodes, 1, 78-92.

[25] Nejjari, C., Filleul, L., Zidouni, N., Laid, Y., Atek, M., El Meziane, A. and Tessier, J.F. (2003) Air Pollution: A New Respiratory Risk for Cities in Low-Income Countries. International Journal of Tuberculosis and Lung Disease, 7, $223-$ 231.

[26] Atk, M., Laid, Y., Oudjehane, R., Zidouni, N., Flleul, L., Tessier, J.F., Boughedaoui, M. and Baough, L. (2004) Effets sanitaires de la pollution atmosphérique urbaine en Afrique du nord: Cas de la ville d'Alger. The International Journal of Tuberculosis Lung Disease, 8, S20.

[27] Laid, Y., Atek, M., Oudjehane, R., Filleul, L., Baough, L., Zidouni, N., Boughedaoui, M. and Tessier, J.F. (2007) Health Effects of PM10 Air Pollution in a Low Income Country: The Case of Algiers? The International Journal of Tuberculosis and Lung Disease, 10, 1406-1411.

[28] Kerbachi, R., Boughedaoui, M., Keddam, M. and Bounoua, L. (2006) Ambient Air Pollution by Aromatichydrocarbons in Algiers. Atmosphric Environment, 40, 3995-4003.

[29] Kerbachi, R., Kerchich, Y. and Khatraoui, H. (2011) Cartographie de la pollution de l'air par les BTEX dans le grand-Alger. Premier colloque francophone, Polluants organiques générées par l'agriculture et les transports, Agadir, 25-27.

[30] Mayer, H. (1999) Air Pollution in Cities. Atmospheric Environment, 33, 4029-4037. http://dx.doi.org/10.1016/S1352-2310(99)00144-2

[31] Kerbachi, R., Boughedaoui, M., Boumechhour, F. and Oucher, N. (2003) Etude de la pollution de l'air par les particules fines $\left(\mathrm{PM}_{10}, \mathrm{PM}_{2.5}\right.$ et $\left.\mathrm{PM}_{1}\right)$ et évaluation de l'aérosol acide à Alger. Proceeding of the 12ème colloque International Transport et Pollution de l'Air, Avignon, 15-17 juin 2003, 93-98.

[32] Boughedaoui, M., Kerbachi, R., Kessali, D. and Joumard, R. (2004) Mesure de la pollution plombifère dans l'air ambient d'Alger. Pollution Atmosphérique, 181, 105-111.

[33] Ecole Nationale d'Application des Techniques de Transport Terrestre (ENATT) (2005) Etude diagnostic sur les Areas à risques de la pollution atmosphérique et sonore "Ville de Batna".

[34] Direction de la wilaya et de l’Aménagement du Territoire (DPAT) (2008).

[35] Direction de la Réglementation et de l’Administration Générale (DRAG) Batna (2012).

[36] Boukahilat, H. (2011) Evaluation des gains énergétiques et des émissions évitées lors de la mise en place d'une nouvelle organisation des déplacements avec étude de cas, Ecole Doctorale en Energétique et Développement Durable, Ecole des mines de Nantes, Mémoire de Magister, option “Management de Projet Energétique”.

[37] Decret exécutif No. 03-410 du ramadhan 1424 correspondant au 5 novembre 2003, fixant les seuils limites des émissions des fumées des gaz toxiques et des bruits par les vehicles automobiles.

[38] Rapport, L.A. (1999) Inventaire des émissions de polluants atmosphériques en régions centre (France). 
Scientific Research Publishing (SCIRP) is one of the largest Open Access journal publishers. It is currently publishing more than 200 open access, online, peer-reviewed journals covering a wide range of academic disciplines. SCIRP serves the worldwide academic communities and contributes to the progress and application of science with its publication.

Other selected journals from SCIRP are listed as below. Submit your manuscript to us via either submit@scirp.org or Online Submission Portal.
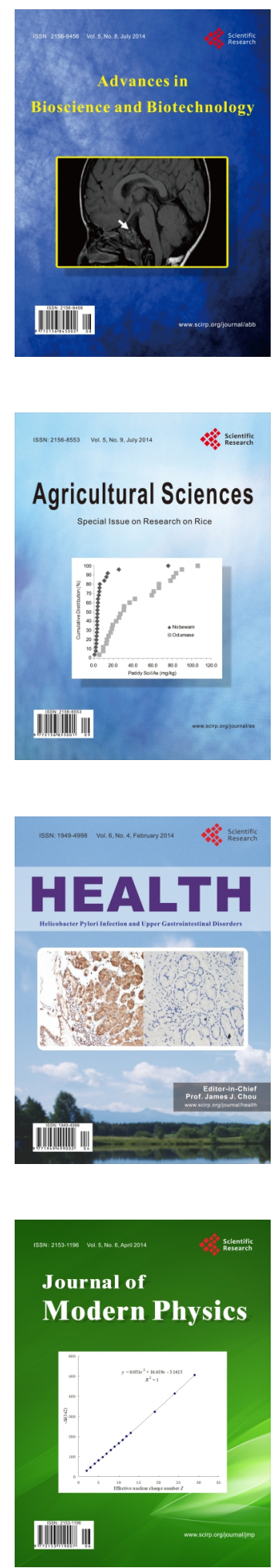
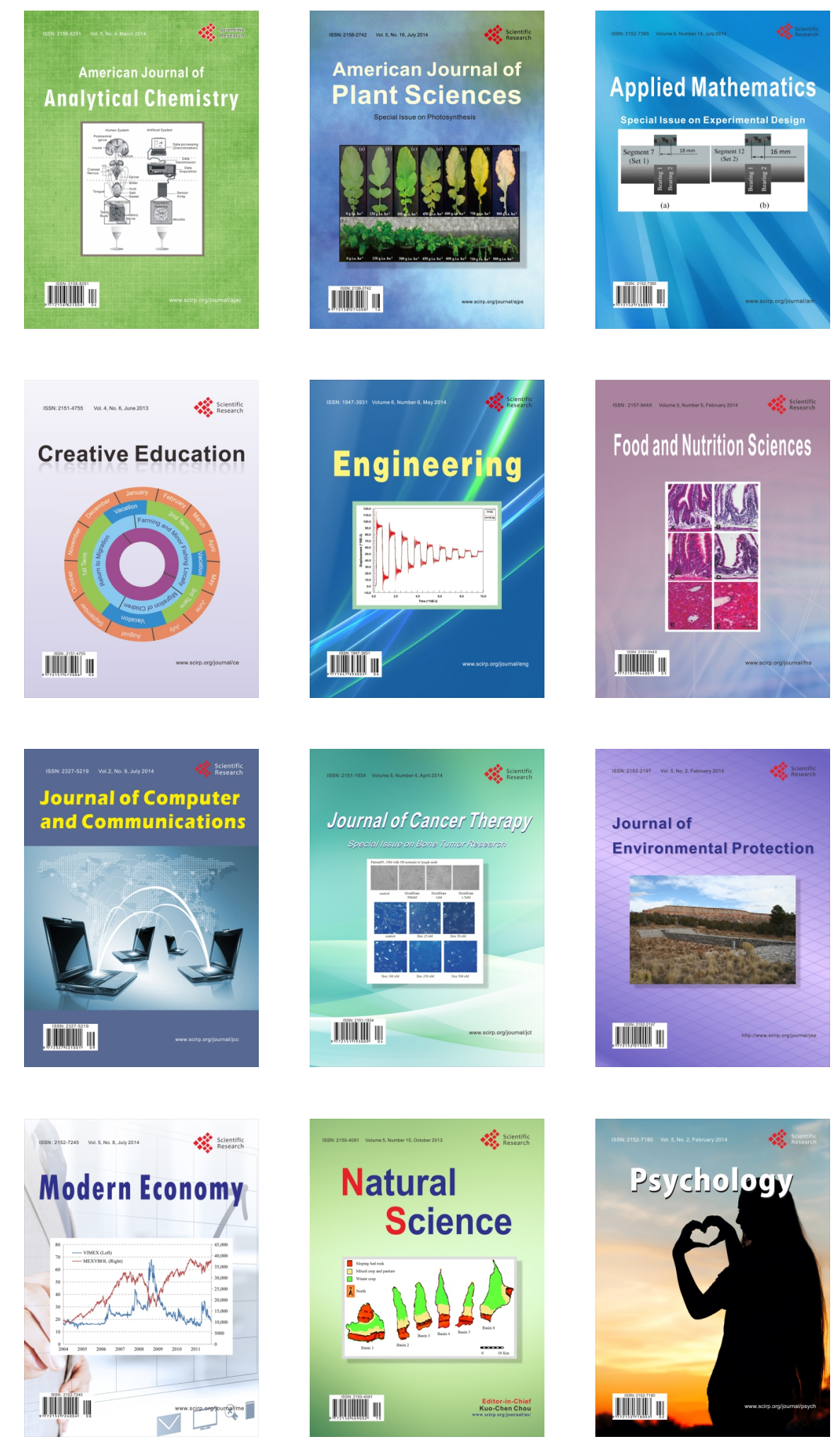